\title{
Corporate Governance And Its Effect On Professional Performance In Palestinian Private Universities, In Light Of Quality, Accreditation, And Classification Requirements
}

https://doi.org/10.21272/sec.5(3).51-60.2021

Dr. Issam Buhaisi, ORCID: https://orcid.org/0000-0002-4886-6546

Full Professor and Dean of Finance and Business Administration faculty, University of Palestine, Palestine

Dr. Zyad Al Damagh, ORCID: https://orcid.org/0000-0003-1938-8335

Associated Professor of Accounting and Finance department, Academic Vice President, University of Gaza, Palestine

\begin{abstract}
Corporate governance has become a subject of heightened importance and attention in government policy circles, academia, and the popular press throughout all over the world. The purpose of the study is to examine the actual status of corporate governance principles in Palestinian private universities at Gaza Strip Governorates, in order to propose a framework of governance for these universities, in light of quality, accreditation and classification requirements for Palestinian universities issued by Palestinian Ministry of Higher Education. In Gaza Strip Governorates there are four private universities, the study covers all these four universities.
\end{abstract}

To achieve the study objectives, the descriptive analytical approach was implemented. The study population includes all the 458, stockholders, academic and administrative fixed contract employees at the four private universities in Gaza Strip. the sample was a random sample of 200 employees (44\% of the population). A special questionnaire was prepared and distributed for the sample, 182 completed and correct questionnaire copies were collected (91\% of total sample). Data was collected using Statistical Package for the Social Sciences "SPSS" program.

The main finding of the study demonstrates that there is a significant relationship between private universities performance and the application of corporate governance principles, quality and accreditation requirements and classification requirements of Ministry of Higher Education (MOHE), and applied corporate governance framework, and there is a middle level of adequacy of corporate governance principles adequacy at private universities in Gaza Governorates. These findings reflect the actual situation of all Palestinian private universities.

Based on the study results, the researchers recommend to build national standards for university governance, aiming to accelerate the issuance of a guide to the governance of private universities. Also, promoting cultural and knowledge awareness regarding the governance of private universities. These recommendations will help Palestinian private universities to achieve higher performance quality in both academic and managerial aspects, this will improve the outcomes of these universities and will be reflected in the capabilities of their graduate students.

Keywords: corporate governance, Private Palestinian universities, accreditation and classification requirements.

JEL Classification: M14.

Cite as: Buhaisi, I., Damagh Al Z. (2021). Corporate Governance And Its Effect On Professional Performance In Palestinian Private Universities, In Light Of Quality, Accreditation, And Classification Requirements. SocioEconomic Challenges, 5(3), 51-60. https://doi.org/10.21272/sec.5(3).51-60.2021.

Received: 16.07 .2021

Accepted: 06.09.2021

Published: 13.09.2021 

access article distributed under the terms and conditions of the Creative Commons Attribution (CC BY) license (https://creativecommons.org/licenses/by/4.0/).

\section{Introduction}

Corporate governance has become a subject of heightened importance and attention in government policy circles, academia, and the popular press throughout all over the world. Various reasons explain the current prominence of what many persons might otherwise consider an arcane and technical topic. The recent financial scandals affecting major American firms, such as Enron, WorldCom, and Arthur Andersen, and the resulting loss of confidence by the investing public in the stock market have led to dramatic declines in share prices and substantial financial losses to millions of individual investors (Salacuse, 2002).

Nowadays good governance became essential in aiding higher education institutions to improve academic quality and to position themselves in the current context characterized by globalization and economic challenges (Evylen, and Sinikiwe, 2016). The Governance of higher education institutions (HEI) has become the focus for much study and comment both at the level of National and Regional Governments. The public has become more interested than ever in the responsiveness of HEI to the needs of the economy a fact that has much to do with the realizationthat HEI have a monumentally important role in the economic development of a nation. It has also been the case that public administration and political leadership has been frequently lead by graduates of the university system. The more the university did not engage with its community the greater was its implied sophistication and its adherence to the historical claim on the ancient origins of the university as an institution and as a centre of intellectual development and presence. In more recent times there has been a demand from Governments and from the greater public for a more intimate engagement of the university with them. Whereas many universities have responded dynamically to those expectations, it was the case that the greater majority did not. This resistance to engagement with Government and its needs provoked Governments to establish universities with a legislative base and governance structures that would ensure that they would be responsive. Indeed, Governments also established new types of higher education institutions which, while not being formal universities, occupied or shared much of the space previously occupied by the universities alone; thus was born the new and more inclusive term 'the higher education institution' (Sita et al., 2018).

\section{State of problem}

The demand of higher education services in Palestine is increasing every year which make the capacity of higher education services organized by the government is no longer able to accommodate all prospective students so they come to private universities to meet those needs. This makes the competition among private universities in Palestine to be increasingly stringent. The issue of good corporate governance is growing rapidly as the same as in Palestine, such as in around the world. The implementation of good CorporateGovernance concept in Universities is expected to increase the added value for all concerned parties (stakeholders).Good Corporate Governance Practices has not been widely applied in themanagement of higher education in private universities in Palestine.

In this study the authors selected three major private universities in Gaza Governorates Governorates: University of Palestine, University of Gaza, and Al Israa University. The study is to examine the actual status of corporate governance principles in these universities, in order to propose a framework of governance for these universities, in light of quality, accreditation and classification requirements for Palestinian universities issued by Palestinian Ministry of Higher Education.

\section{Study variables}

1. Dependent variables
a. Corporate governance principles;
b. Quality and accreditation requirements;
c. Classification requirements; 
d. Corporate governance framework.

2. Independent variable

e. Performance of private university in Gaza Strip Governorates.

\section{Study Hypothesis}

The study tries to examine the following hypothesis

1. There is no significant relationship at the level $\alpha=0.05 \%$ between corporate governance principles and the performance of private universities in Gaza Governorates.

2. There is no significant relationship at the level $\alpha=0.05 \%$ between quality and accreditation requirements and the performance of private universities in Gaza Governorates.

3. There is no significant relationship at the level $\alpha=0.05 \%$ between classification requirements and the performance of private universities in Gaza Governorates.

4. There is no significant relationship at the level $\alpha=0.05 \%$ between Governance framework and the performance of private universities in Gaza strip Governorates.

\section{Theoretical Framework}

The term "corporate governance" appears to have arisen and entered into prominent usage in the mid-to-late 1970's in the United States in the wake of the Watergate scandal and the discovery that major American corporations had engaged in secret political contributions and corrupt payments abroad (Veasey, 1993). Eventually it also gained currency in Europe as a concept distinct from corporate management, company law or corporate organization. Scholars and practitioners of corporate governance give the term a wide variety of definitions. Economists and social scientists tend to define it broadly as the institutions that influence how business corporations allocate resources and returns (O'Sullivan, 2000). Also it is known as the system of rules and institutions that determine the control and direction of the corporation and that define relations among the corporation's primary participants (Cadbury Report, 1992). As applied in practice, this narrower definition focuses almost exclusively on the internal structure and operation of the corporation's decision-making processes.Other definition, states that Corporate Governance defines relationships and the distribution of rights and responsibilities amongst those who work with and in the organization, determines the rules and procedures through which the organization's objectives are set, and provides the means of attaining those objectives and monitoring performance. Importantly, it defines where accountability lies throughout the organization (Cabinet Office, 2009).

Often the most readily identifiable elements of a Corporate Governance Framework are the organization's formal Boards and Committees, by which the organization is led. Good governance means having a clear statement of their respective roles and responsibilities and how they relate to each other. Jingyang (2016).

Discussing the influence of the implementation of Good University Governance on the education quality in private universities in Makassar (Indonesia), Sita et al. (2018) found that the implementation of good university governance significantly and directly affects the education quality. Jingyang (2016) argued that the implementation of good governance in non profit university lead to improve the teaching process and to increase transparency, accountability in these institutions.

Examining the relationship between corporate governance and financial performance among private universities in Uganda, Tusubira and Issac (2013) found that corporate governance variables negatively affected financial performance, they argued that policy and decision making are significant predictors of financial performance. Corporate governance variable are significant predictors of board roles, board roles are significant predictors of board effectiveness, and contingency is a significant predictor of board roles and effectiveness.

Normally, private colleges and universities belong to higher education service agencies, colleges and universities need to train people management services. Improve the corporate governance structure conducive environment to create a good university governance from top to bottom, to better achieve the purpose of training people (Haitao and Wnmei, 2015). Pay attention to the legal concept of good governance, emphasizing transparency and 
accountability, human environment and school culture fit, help enhance students' sense of responsibility and sense of the rule of law. Second, the pursuit of the same goal. Good governance private colleges and universities are seeking to maximize the public interest, the driving force of the non-profit private colleges and universities for the public goal, the ultimate goal of good governance is to maximize the public interest. Thus, the pursuit of the ultimate goal of a non-profit private colleges and universities have consistency and good governance. Under the existing legal framework, combined with the special nature of the theory of good governance and corporate governance structure of the non-profit, non-profit corporate governance structure of private colleges and universities can be improved from the following aspects. The first corporate governance structure established as the core framework for the chairman, board of directors, principals, independent internal oversight bodies and constraints. Current corporate governance structure of private colleges and universities vary, the advantages of various types of corporate governance structure is different. However, different structures easily lead to differences in division of responsibilities, cannot be implemented unified supervision. Therefore, for the national requirements for private colleges and universities, private colleges and universities need to establish a board of directors as the core legal body, the board of directors, the rights belong to the principal organs and executive bodies, internal oversight in part, internal discipline department. Currently many private schools in developed countries have established a board of directors as the core of corporate governance mechanism (Jianin, 2008).

The main reason for the dispute and the powers of the Board of Directors is private school system is not perfect, and therefore need to improve the details of the board of directors system. Board internal structure, you need to specify the details of the number of personnel, board members and the method of qualification, term of office; power aspects need to be laws or regulations expressly define the scope of the powers and responsibilities of the Board, the directors to prevent interference teaching. Incentives, can learn the reputation mechanism, limit the use of the reputation of the Board of behavior. Use reputation mechanisms need to select people from other schools, both can learn from the experiences of other schools, but also can promote the maintenance of personal reputation and to participate in activities of the Board. (Yonglon and Lei, 2014).

Studying the status of the implementation of the principles of governance of universities in the Gaza Strip. Dehdar et al. (2017) found that there is a lack of the role played by the Ministry of Higher Education to support the universities, also they found that Palestinian universities in the Gaza Strip practicing the principles of corporate governance in a fair degree.

\section{Higher Education in Palestine}

Higher education (HE) in Palestine was regulated through the Law on Higher Education No 11 of 1998. This law gives every citizen the possibility to access higher education (Article 2), gives legal status to HE Institutions (HEIs) and provides the legal framework for their organization and management. The law recognizes three different types of institutions in HE. These are governmental, public (established by non-governmental organizations), and private institutions. The Council of Higher Education is responsible for drafting and enacting the rules that all higher education institutions must adopt. The HEIs are mostly independent but they have to follow the abovementioned law, regulations of the Ministry of higher Education (MOHE) and the Council for Higher Education (CFHE).(MOHE, 2016). The majority of the 49 Palestinian HEIs in the West Bank and Gaza Strip are relatively young. The first established one is BirZeit University that has been established at 1971.n In Gaza strip, the Islamic University of Gaza was funded at 1978 as a first higher education institute. Actually there is 27 higher education institutions in Gaza Governorates, as Table 1.

Table 1. Higher Education Institutions in Gaza Strip

\begin{tabular}{|l|l|c|c|c|c|c|}
\hline & \multicolumn{1}{|c|}{ Type of Institution } & Public & Governmental & Private & UNRWA & Total \\
\hline 1 & Universities & 3 & 1 & 4 & 0 & 8 \\
\hline 2 & University College & 1 & 5 & 1 & 0 & 7 \\
\hline 3 & Polytechnic & 0 & 0 & 1 & 0 & 1 \\
\hline 4 & Middle college & 1 & 1 & 7 & 2 & 11 \\
\hline & Total & 5 & 7 & 13 & 2 & 27 \\
\hline
\end{tabular}

Source: PCBS - Statistical Book of Palestinian Education (2019), Vol. 2, pp. 48. 
At the end of 2019 there were more than 12000 students enrolled in the four private universities in Gaza Strip (PCBS - Statistical Book of Palestinian Education (2019), Vol. 2, pp. 50).

In accordance with international norms, the Law on Higher Education No 11 of 1998 combines two approaches:

$>$ Central national planning and supervision by MOHE and SFHE;

$>$ Self-management, self-monitoring and self-control at institutional level.

This means that higher education institutions enjoy autonomy and self-management. They are responsible for admissions, recruitment of staff, assessment of students, granting of degrees and diplomas and the development of facilities. In addition to the Council of Higher Education, a Council for Scientific Research and a National Commission for Accreditation and Quality Assurance (AQAC) were set up. Although the Council for Higher Education was reactivated in 2003, its relationship with the institutions of higher education should be better organized, structured and institutionalized. Coordination and cooperation between the MOHE and the institutions, and among the institutions themselves, need to be strengthened. Management information systems at institutional level and at central ministry level still need to be improved, harmonized and interfaced and the skills of the MOHE staff to update and their use for decision-making have to be further developed. Important policies and strategies approved by the MOHE and the Council for Higher Education are not adhered to at institutional level. Institutions still do not appreciate the regulatory, planning and developmental role which the MOHE can play and which is needed to link higher education to the needs of the labor market. The Palestinian quality assurance policy was upgraded in 2002 simultaneously with the establishment of the Accreditation and Quality Assurance Commission (AQAC) as the only authorized agency responsible for the accreditation and quality assurance of Higher Education. The AQAC is a governmental semiautonomous body under the umbrella of the Ministry of Education and Higher Education (MOHE) and responsible directly to the Minister. The Palestinian QA system is based on the belief that internal QA is the basis for external QA evaluation. External QA evaluation is compulsory, and applies to public and private institutions, university and nonuniversity sectors and all types of academic and vocational programs.

\section{Methodology}

To achieve the study objectives, the descriptive analytical approach was implemented. The study population includes all the 458, stockholders, academic and administrative fixed contract employees at the four private universities in Gaza Strip. the sample was a random sample of 200 employees (44\% of the population). A special questionnaire was prepared and distributed for the sample, 182 completed and correct questionnaire copies were collected (91\% of total sample). the sample characteristics are presented in Table 2.

Table 2. Sample characteristics

\begin{tabular}{|c|c|c|c|}
\hline \multicolumn{2}{|r|}{ Character } & Frequency & Percent \\
\hline \multirow{3}{*}{ Gender } & Male & 145 & $79.7 \%$ \\
\hline & Female & $\underline{37}$ & $20.3 \%$ \\
\hline & Total & 182 & $100 \%$ \\
\hline \multirow{3}{*}{ Legal Relationship Nature } & Stockholders & 3 & $1.6 \%$ \\
\hline & Employee & $\underline{179}$ & $98.4 .3 \%$ \\
\hline & Total & $\overline{182}$ & $100 \%$ \\
\hline \multirow{8}{*}{ Position } & University President & 1 & $0.5 \%$ \\
\hline & University Vice President & 3 & $1.5 \%$ \\
\hline & Faculty Dean & 6 & $3 \%$ \\
\hline & Head of Academic Department & 11 & $6 \%$ \\
\hline & Director of administrative Unit & 16 & $9 \%$ \\
\hline & Lecturer & 118 & $65 \%$ \\
\hline & Administrative & $\underline{27}$ & $\underline{15 \%}$ \\
\hline & Total & $\overline{182}$ & $100 \%$ \\
\hline \multirow{5}{*}{$\begin{array}{l}\text { Experience in the current } \\
\text { university }\end{array}$} & Less than 3 years & 2 & $1 \%$ \\
\hline & $3-5$ years & 11 & $6 \%$ \\
\hline & $5-7$ years & 59 & $33 \%$ \\
\hline & More than 7 years & 110 & $60 \%$ \\
\hline & Total & 182 & $100 \%$ \\
\hline
\end{tabular}

Source: Elaborated by authors as a result of statistical analysis. 
Table 2 shows that the sample characteristics almost reflect the study publication characteristics.

\section{Data analysis}

Data analysis of the 182 completed and correct questionnaire was done using SPSS program. Results are presented in the following tables.

Table 3 presents the response of the employees about adequacy level of corporate governance principles adequacy at private universities in Gaza Governorates.

Table 3. Adequacy level of corporate governance principles

\begin{tabular}{|l|l|c|c|c|c|c|}
\hline \multicolumn{1}{|c|}{ Principle } & Med & $\begin{array}{c}\text { Standard } \\
\text { Deviation }\end{array}$ & Weight & $\begin{array}{c}\text { Adequacy } \\
\text { Level }\end{array}$ & Ranking \\
\hline 1 & $\begin{array}{l}\text { Stockholders rights principle is adequate in } \\
\text { your university }\end{array}$ & 3.94 & 0.82 & $78.8 \%$ & Middle & 4 \\
\hline 2 & $\begin{array}{l}\text { Board of Directors rights principle is } \\
\text { adequate in your university }\end{array}$ & 3.96 & 0.86 & $79.2 \%$ & Middle & 2 \\
\hline 3 & $\begin{array}{l}\text { Operational management tasks principle is } \\
\text { adequate in your university }\end{array}$ & 3.96 & 0.83 & $79.2 \%$ & Middle & 3 \\
\hline 4 & $\begin{array}{l}\text { Stakeholders rights principle is adequate in } \\
\text { your university }\end{array}$ & 3.88 & 0.85 & $77.6 \%$ & Middle & 6 \\
\hline 5 & Disclosing principle is adequate & 3.90 & 0.81 & $77.9 \%$ & Middle & 5 \\
\hline 6 & $\begin{array}{l}\text { Auditing and control principle is adequate } \\
\text { in your university }\end{array}$ & 3.97 & 0.83 & $79.3 \%$ & Middle & 1 \\
\hline 7 & Average & $\mathbf{3 . 9 4}$ & $\mathbf{0 . 8 3}$ & $\mathbf{7 6 . 7 . 0 \%}$ & Middle & \\
\hline
\end{tabular}

Source: Elaborated by authors as a result of statistical analysis.

Table 3 shows that a corporate governance principles has a meddle adequacylevel in the Palestinian universities at Gaza Strip, with 3.94 average and $76.7 \%$ importance weight average , all the axis components also have the same level of adequacywith little difference between them. In the adequacy ranking, the first principle was Auditing and control principle and the last one was Stakeholders rights principle. The standard deviation is low (0.83) and almost the same in all the axis components which means that there is a consensus of opinions.

Table 4 presents the responses of the employees about the adequacy level of accreditation requirements standards established by the Ministry of higher Education in Palestine.

Table 4. Adequacy level of accreditation requirements standards established by MOHE

\begin{tabular}{|c|c|c|c|c|c|c|}
\hline & Principle & Med & $\begin{array}{c}\text { Standard } \\
\text { Deviation }\end{array}$ & Weight & $\begin{array}{c}\text { Adequacy } \\
\text { Level }\end{array}$ & Ranking \\
\hline 1 & Structuring standard is adequate & 4.08 & 0.68 & $81.6 \%$ & High & 4 \\
\hline 2 & Planning efficiency standard is adequate & 3.98 & 0.69 & $79.6 \%$ & Middle & 8 \\
\hline 3 & Financial Resources standard is adequate & 3.80 & 0.67 & $76.0 \%$ & Middle & 11 \\
\hline 4 & Transparency standard is adequate & 3.92 & 0.70 & $78.4 \%$ & Middle & 10 \\
\hline 5 & $\begin{array}{l}\text { Academic and administrative Staff } \\
\text { standard is adequate }\end{array}$ & 4.05 & 0.71 & $81.0 \%$ & High & 6 \\
\hline 6 & Quality Guarantee standard & 3.97 & 0.67 & $79.4 \%$ & Middle & 9 \\
\hline 7 & Student affairs standard e is adequate & 4.12 & 0.67 & $82.4 \%$ & High & 3 \\
\hline 8 & Learning sources standard is adequate & 4.21 & 0.68 & $84.2 \%$ & High & 1 \\
\hline 9 & $\begin{array}{l}\text { Academic program evaluation standard is } \\
\text { adequate }\end{array}$ & 4.18 & 0.67 & $83.6 \%$ & High & 2 \\
\hline 10 & Scientific research standard e is adequate & 4.01 & 0.71 & $80.2 \%$ & High & 7 \\
\hline 11 & Social participation standard is adequate & 4.07 & 0.63 & $81.4 \%$ & High & 5 \\
\hline & Average & 4.02 & 0.68 & $\mathbf{8 0 . 7 1 \%}$ & High & \\
\hline
\end{tabular}

Source: Elaborated by authors as a result of statistical analysis.

Table 4 shows that accreditation requirements standards established by the Ministry of higher Education in Palestine have a high level en general. The components of this axis are vary in the adequacy level. Seven of these standards have a high level of adequacy, while the other six standards have a meddle level. Learning sources 
standard is the most adequate standard (4.21 average), while Financial Resources standard is the lowest one (3.8averag). The standard deviation is low (0.68) and similar in all the axis components which means that there is a consensus of opinions.

Table 5 present responses of the employees about the adequacy level of university classification requirements standards established by the Ministry of higher Education in Palestine.

Table 5. Adequacy level of university classification requirements standards established by the MOHE

\begin{tabular}{|c|c|c|c|c|c|c|}
\hline & Principle & Med & $\begin{array}{c}\text { Standard } \\
\text { Deviation }\end{array}$ & Weight & $\begin{array}{l}\text { Adequacy } \\
\text { Level }\end{array}$ & Ranking \\
\hline 1 & $\begin{array}{l}\text { University environment and learning quality } \\
\text { indicator is adequate }\end{array}$ & 4.12 & 0.77 & $82.4 \%$ & High & 2 \\
\hline 2 & $\begin{array}{l}\text { Scientific research, innovation and population } \\
\text { indicator is adequate }\end{array}$ & 3.80 & 0.97 & $76.0 \%$ & Middle & 3 \\
\hline 3 & Community interaction indicator is adequate & 4.13 & 0.67 & $82.6 \%$ & High & 1 \\
\hline 4 & Global Reach indicator is adequate & 3.80 & 0.98 & $76.0 \%$ & Middle & 4 \\
\hline 5 & Average & 3.53 & $\mathbf{0 . 8 5}$ & $70.6 \%$ & Middle & 2 \\
\hline
\end{tabular}

Source: Elaborated by authors as a result of statistical analysis.

Table 5 shows a middle level of adequacy level of university classification requirements standards established by the Ministry of higher Education in Palestine. Among these indicators, tow indicators has a high level of adequacy, Community interaction indicator (4.13 average and 0.67 Standard Deviation) and University environment and learning quality indicator is adequate (4.12 average and 0.77 Standard Deviation). the remain indicators have a middle level of adequacy as shown in the table. Standard deviation average (0.85) is low and the differences between the standard deviation of all components is so small which means that there is almost a consensus of opinions.

Table 6 present the responses of the employees about the adequacy level of private universities performance.

Table 6. The level of private universities performance

\begin{tabular}{|c|c|c|c|c|c|c|}
\hline & Principle & Med & $\begin{array}{l}\text { Standard } \\
\text { Deviation }\end{array}$ & Weight & $\begin{array}{l}\text { Adequacy } \\
\text { Level }\end{array}$ & Ranking \\
\hline 1 & $\begin{array}{l}\text { University structure is adequate for corporate } \\
\text { governance }\end{array}$ & 3.36 & 0.95 & $67.3 \%$ & Middle & 13 \\
\hline 2 & $\begin{array}{l}\text { University Mission, Vision and objectives are } \\
\text { adequate to its expectations }\end{array}$ & 4.05 & 0.82 & $81.1 \%$ & High & 3 \\
\hline 3 & $\begin{array}{l}\text { All parties participate in strategic planning of } \\
\text { the university }\end{array}$ & 3.65 & 1.70 & $73.0 \%$ & Middle & 7 \\
\hline 4 & $\begin{array}{l}\text { The University tries to implement corporate } \\
\text { governance and transparency principles }\end{array}$ & 3.28 & 0.94 & $65.6 \%$ & Middle & 16 \\
\hline 5 & $\begin{array}{l}\text { University financial resources are enough and } \\
\text { adequate to implement its operational activities } \\
\text { and development plans }\end{array}$ & 3.52 & 1.13 & $70.4 \%$ & Middle & 9 \\
\hline 6 & $\begin{array}{l}\text { The university enhances its position and } \\
\text { reliability by disclosing a full information } \\
\text { about its activities }\end{array}$ & 3.56 & 0.88 & $71.2 \%$ & Middle & 8 \\
\hline 7 & $\begin{array}{l}\text { The university publishes its audited Balance } \\
\text { Sheet }\end{array}$ & 2.90 & 0.83 & $58.0 \%$ & Low & 19 \\
\hline 8 & $\begin{array}{l}\text { The university tries to attract high qualified } \\
\text { human resources to work in the university }\end{array}$ & 3.87 & 0.98 & $77.5 \%$ & Middle & 4 \\
\hline 9 & $\begin{array}{l}\text { The university encourages its staff to } \\
\text { implement the available teaching and learning } \\
\text { resources in their courses }\end{array}$ & 3.82 & 0.85 & $76.5 \%$ & Middle & 5 \\
\hline 10 & $\begin{array}{l}\text { The university encourages its academic staff to } \\
\text { get high qualification in abroad }\end{array}$ & 2.32 & 1.13 & $46.5 \%$ & Low & 21 \\
\hline
\end{tabular}


Table 6 (cont.). The level of private universities performance

\begin{tabular}{|c|c|c|c|c|c|c|}
\hline & Principle & Med & $\begin{array}{l}\text { Standard } \\
\text { Deviation }\end{array}$ & Weight & $\begin{array}{c}\text { Adequacy } \\
\text { Level }\end{array}$ & Ranking \\
\hline 11 & $\begin{array}{l}\text { The university develops its procedures and } \\
\text { policies to enhance the Effectiveness of quality } \\
\text { assurance mechanisms }\end{array}$ & 3.72 & 0.74 & $74.4 \%$ & Middle & 6 \\
\hline 12 & $\begin{array}{l}\text { The university conducts a feasibility study for } \\
\text { its programs using labor force market data }\end{array}$ & 2.70 & 0.95 & $54.0 \%$ & Low & 20 \\
\hline 13 & $\begin{array}{l}\text { The university studies the future requirements } \\
\text { of its graduates in local, regional and } \\
\text { international context. }\end{array}$ & 3.36 & 0.87 & $67.3 \%$ & Middle & 14 \\
\hline 14 & $\begin{array}{l}\text { The university engages its students in } \\
\text { extracurricular activities that develop their } \\
\text { awareness }\end{array}$ & 3.49 & 0.94 & $69.9 \%$ & Middle & 10 \\
\hline 15 & $\begin{array}{l}\text { The university provides its students with the } \\
\text { necessary training during their studies }\end{array}$ & 3.32 & 1.06 & $66.5 \%$ & Middle & 15 \\
\hline 16 & $\begin{array}{l}\text { The university involves employers of its } \\
\text { graduates and professional bodies in evaluating } \\
\text { and developing its educational programs }\end{array}$ & 3.01 & 0.90 & $60.2 \%$ & Middle & 18 \\
\hline 17 & $\begin{array}{l}\text { The university has a comprehensive guide for } \\
\text { auditing and control procedures }\end{array}$ & 3.04 & 0.88 & $60.9 \%$ & Middle & 17 \\
\hline 18 & The university protects stakeholders interests & 3.48 & 0.78 & $69.7 \%$ & Middle & 11 \\
\hline 19 & $\begin{array}{l}\text { The board of directors delegates authority to } \\
\text { the presidency and the university council. }\end{array}$ & 3.38 & 1.01 & $67.6 \%$ & Middle & 12 \\
\hline 20 & $\begin{array}{l}\text { The university is negatively affected by the } \\
\text { increasing number of private universities in } \\
\text { Gaza strip }\end{array}$ & 4.26 & 0.94 & $85.3 \%$ & High & 2 \\
\hline \multirow[t]{2}{*}{21} & $\begin{array}{l}\text { The university's negatively affected by the } \\
\text { Political conditions in Palestinian territories }\end{array}$ & 4.38 & 0.97 & $87.7 \%$ & High & 1 \\
\hline & & 3.29 & 0.94 & $65.8 \%$ & Middle & \\
\hline
\end{tabular}

Source: Elaborated by authors as a result of statistical analysis.

Table 6 shows that the most important factors that affect the university performance are the increasing number of private universities in Gaza strip and the Political conditions in Palestinian society territories and both have a negative impact, while University Mission, Vision and objectives are adequate to its expectations. Other distinguished facts are the universities do not publish their audited Balance Sheet and they do not encourages its academic staff to get high qualification in abroad. All other components have middle level of acceptance. In general this axis have a middle level of acceptance. Standard deviation average (0.94) is low and the differences between the standard deviation of all components is so small which means that there is almost a consensus of opinions. These results indicates that private universities in Palestine must do more effort to increase their performance toward archiving a good corporate governance level.

\section{Hypothesis examination}

To examine the study hypothesis and to explain the relationship between the dependent variable (Performance of private university in Gaza Strip Governorates ) and each one of the independent variables, we used a simple regression. Tables 7 and 8 show the results of this analysis. (No. of observations is 182).

Table 7. Regression analysis main data

\begin{tabular}{|l|c|c|c|c|}
\hline Variable & $\mathrm{R}^{2}$ & Adjusted $\mathrm{R}^{2}$ & $\mathrm{~F}$ value & Sig \\
\hline Corporate governance principles & 0.316 & 0.284 & $13.410^{* *}$ & 0.001 \\
\hline Quality and accreditation requirements & 0.282 & 0.253 & $20.69^{* *}$ & 0.000 \\
\hline Classification requirements & 0.305 & 0.278 & $21.965^{* *}$ & 0.000 \\
\hline Governance framework & 0.236 & 0.214 & $21.612^{* *}$ & 0.000 \\
\hline
\end{tabular}

Source: Elaborated by authors as a result of statistical analysis. 
Table 7 shows that the used simple regression can explain $31.6 \%-28.4 \%$ between the dependent variable and the independent variable: Corporate governance principles. $28.2 \%-25.3 \%$ between the dependent variable and the independent variable and the independent variable: Quality and accreditation requirements. 30.5\% $-27.8 \%$ between the dependent variable and the independent variable Classification requirements. $23.6 \%-21.4 \%$ between the dependent variable and the independent variable Governance framework. F value is significant in all cases.

Table 8. Beta value, and $\mathrm{T}$ value of the relationship between dependent variable and each one of dependent variables

\begin{tabular}{|l|c|c|c|c|c|}
\hline \multicolumn{1}{|c|}{ Variable } & B & Std. Error & $\begin{array}{c}\text { Beta } \\
\text { Value }\end{array}$ & T Value & Sig \\
\hline Corporate governance principles & 0.171 & 0.051 & 0.244 & $3.372^{* *}$ & 0.001 \\
\hline Quality and accreditation requirements & 0.302 & 0.057 & 0.240 & $4.250^{* *}$ & 0.000 \\
\hline Classification requirements & 0.325 & 0.05 & 0.233 & $4.613^{* *}$ & 0.000 \\
\hline Governance framework & 0.312 & 0.056 & 0.247 & $4.406^{* *}$ & 0.000 \\
\hline
\end{tabular}

Source: Elaborated by authors as a result of statistical analysis.

Table 8 shows Beta value, and $\mathrm{T}$ value to examine the hypothesis that explain the relationship between dependent variable (Performance of private university in Gaza Strip Governorates) and each one of dependent variables.

First hypothesis: There is no significant relationship at the level $\alpha=0.05 \%$ between corporate governance principles and the performance of private universities in Gaza strip Governorates. Date in Table 8 shows that there is a significant relationship at the level $\alpha=0.05 \%$ between corporate governance principles and the performance of private universities in Gaza strip Governorates. So we will refuse the null hypotheses.

Second hypothesis: There is no significant relationship at the level $\alpha=0.05 \%$ between quality and accreditation requirements and the performance of private universities in Gaza strip Governorates. Date in table no. (8) shows that there is a significant relationship at the level $\alpha=0.05 \%$ between quality and accreditation requirements and the performance of private universities in Gaza strip Governorates. So we will refuse the null hypotheses.

Third hypotheses: There is no significant relationship at the level $\alpha=0.05 \%$ between classification requirements and the performance of private universities in Gaza strip Governorates. Date in Table 8 shows that there is a significant relationship at the level $\alpha=0.05 \%$ between. classification requirements and the performance of private universities in Gaza strip Governorates. So we will refuse the null hypotheses.

Fourth hypothesis: There is no significant relationship at the level $\alpha=0.05 \%$ between Governance framework and the performance of private universities in Gaza strip Governorates. Date in Table 8 Shows that there is a significant relationship at the level $\alpha=0.05 \%$ between. Governance framework and the performance of private universities in Gaza strip Governorates. So we will refuse the null hypotheses.

\section{Findings and recommendations}

The main findings of the study were as following:

1. The study argued that there is a significant relationship between private universities performance and the application of corporate governance principles, quality and accreditation requirements of MOHE, classification requirements of MOHE. and applied corporate governance framework.

2. There is a middle level of adequacy of corporate governance principles adequacy at private universities in Gaza Governorates.

The main recommendations of this study are:

1. Private Palestinian universities should give more attention to corporate governance principles, and governance frame work as tools of improving their performance.

2. Palestinian MOHE should continue in its policy of applying a high Quality and accreditation requirements and Classification requirements for Palestinian universities. 
3. The authors see that it is better for private Palestinian universities in Gaza Governorate to be merged in only one university, this will increase the effect of corporate governance on the universities performance.

Funding: self-funded.

Author contribution: conceptualization, Dr. Issam Buhaisi; data curation, Dr. Zyad Al Damagh; formal analysis, Dr. Issam Buhaisi; funding acquisition, Dr. Issam Buhaisi, Dr. Zyad Al Damagh; investigation, Dr. Zyad Al Damagh; methodology, Dr. Issam Buhaisi; project administration, Dr. Issam Buhaisi; resources, Dr. Issam Buhaisi, Dr. Zyad Al Damagh; software, Dr. Issam Buhaisi, Dr. Zyad Al Damagh; supervision, Dr. Issam Buhaisi; validation, Dr. Zyad Al Damagh; visualization, Dr. Zyad Al Damagh; writing - original draft, Dr. Issam Buhaisi; writing - review \& editing, Dr. Issam Buhaisi.

\section{References}

1. Cabinet Office (2009). Corporate Governance in Central Government Departments, p. 9. Available at: [Link].

2. Cadbury Report (2002). Report of the Committee on the Financial Aspects of Corporate Governance. Available at: [Link].

3. Dehdar, M. H., Benkahla, K. and AlFarra, M. (2017). The Reality of Governance in Palestinian Universities. IUG Journal of Economics and Business, 25(1), 62-88. Available at: [Link].

4. Evylen, C.G., and Sinikiwe,T. (2016). A comparison of in universities governing boards in private and public universities. International Research in Higher Education, 1(1), 145-152. Available at: [Link].

5. Jingyang, L. (2016). Study on Corporate Governance Structure of Nonprofit Private Universities based on Good Governance. A research presented to 5th International Conference on Social Science, Education and Humanities Research. Available at: [Link].

6. Liu Jianyin (2008). Perspective from the perspective of non-profit organizations Private School Corporate Governance. Private Education Research, 04, 74-80. Available at: [Link].

7. O'Sullivan, M. (2000). Corporate Governance and Globalization. ANNALS, American Academy of Political Science No. 570, pp. 153-154. Available at: [Link].

8. Palestinian Central Bureau of Statistics (2019). Statistical Book of Palestinian education, 2, pp. 48. Available at: [Link].

9. Palestinian Ministry of Higher Education (2016). Higher Education system In the State of Palestine-Country Modules. Available at: [Link].

10. Salacuse, J. W. (2002). Corporate Governance in the UNECE Region. A Paper commissioned for the Economic Survey of Europe, 2003 No. 1. by the secretariat of the United Nations Economic Commission for Europe. Available at: [Link].

11. Sita Y. S., Amiruddin T., and Chalid I.M. (2018). The Implementation of Good University Governance in the Private Universities in Makassar (Indonesia). ESPACIOS, 39(2), 8-17. Available at: [Link].

12. Tusubira and Issac, N. F. and Isaac, N. N. (2013). Corporate Governance in Private Universities: Financial Performance Perspective. Journal of Business Law and Ethics, 1(1), 1-15. Available at: [Link].

13. Veasey, E.N. (1993). The Emergence of Corporate Governance as a New Legal Discipline, The Business Lawyer No. 48. Available at: [Link].

14. Yin Yonglon, Dai Lei (2014). Behalf of the bud and Measures of Perfecting the Corporate Governance Structure in Private Colleges and Universities. [J]. Value Engineering, 10, 242-243. Available at: [Link].

15. Zhou Haitao, Shi Wenmei (2015). Challenges and strategies to improve the corporate governance structure of Private Colleges. [J] Higher, 4(13), 76-95. Available at: [Link]. 